\title{
Visual outcomes after deep anterior lamellar keratoplasty using donor corneas without removal of Descemet membrane and endothelium
}

\author{
Resultados visuais após transplante lamelar anterior profundo utilizando botão corneano \\ sem remoção da membrana de Descemet e endotélio
}

Tatiana Moura Bastos Prazeres ${ }^{1,2}$, Rodrigo Muller ${ }^{2}$, Tatiana Rayes ${ }^{2}$, Flavio Eduardo Hiral ${ }^{1}$, Luciene Barbosa de Sousa ${ }^{1}$

\begin{abstract}
Purpose: The optical quality of the interface after deep anterior lamellar keratoplasty (DALK) using the big-bubble technique has been shown to be excellent, leading to results comparable to penetrating keratoplasty. However, there is little in the literature with respect to the controversy surrounding the preparation of the donor cornea. The purpose of this study was to evaluate visual acuity (VA) in patients with keratoconus who underwent DALK without removal of the donor graft endothelium.

Methods: The records of 90 patients who underwent DALK without the removal of the Descemet membrane (DM) and endothelium were retrospectively reviewed. Data collected included uncorrected VA (UCVA) and spectacle-correctedVA (SCVA) at 7, 30, 180 days, and 1 year postoperatively. Contact lens-corrected visual acuity (CLVA) was evaluated after 1 year of the procedure.

Results: UCVA was significantly better than preoperative values at 7 days $(p<0.001)$, 30 days $(p<0.001), 180$ days $(p<0.001)$, and 1 year $(p<0.001)$ after surgery. The 1 -year postoperative mean SCVA and CLVA also improved when compared with preoperative SCVA ( $p<0.001$ for both).

Conclusions: DALK utilizing donor corneas with attached Descemet membrane and endothelium results in satisfactory VA in patients with keratoconus.

Keywords: Corneal diseases/surgery; Descemet membrane/surgery; Corneal transplantation/methods; Endothelium, corneal; Keratoplasty, penetrating; Keratonoconus/surgery; Visual acuity
\end{abstract}

\section{RESUMO}

Objetivos: A qualidade óptica da interface após ceratoplastia lamelar anterior profunda (DALK) utilizando a técnica de "Big Bubble" mostrou-se ser excelente, levando a resultados comparáveis aos da ceratoplastia penetrante. No entanto, há poucos dados na literatura com respeito à controvérsia em torno da preparação da córnea doadora. O objetivo deste estudo foi avaliar a acuidade visual (VA) em pacientes com ceratocone submetidos DALK sem a remoção da membrana de descemet e endotélio do tecido doador.

Métodos: Os prontuários de 90 pacientes que foram submetidos a DALK sem a remoção da membrana Descemet (DM) e do endotélio foram avaliados retrospectivamente. Os dados coletados incluíram VA sem correção (UCVA) e VA corrigida por óculos (SCVA) aos 7, 30, 180 dias, e 1 ano de pós-operatório. A acuidade visual corrigida por lente de contato (CLVA) foi avaliada após 1 ano do procedimento.

Resultados: UCVA no pós-operatório melhorou após 7 dias $(p<0,001)$; 30 dias $(p<0,001)$, 180 dias $(p<0,001)$; e após 1 ano $(p<0,001)$. Ocorreu melhora da SCVA pré-operatória quando comparada com a SCVA e CLVA após 1 ano ( $p<0,001$ para ambos).

Conclusão: Transplante lamelar anterior utilizando córneas doadas com membrana de Descemet e endotélio demonstrou resultados visuais satisfatórios em pacientes com ceratocone.

Descritores: Doenças da córnea/cirurgia; Lâmina limitanteposterior/cirurgia; Transplante da córnea/métodos; Epitélio posterior; Ceratoplastia penetrante; Ceratocone/ cirurgia; Acuidade visual

\section{INTRODUCTION}

Traditionally, penetrating keratoplasty (PK) has been indicated to treat keratoconus ${ }^{(1)}$. It is a well-established procedure that provides satisfactory visual outcomes as evidenced by several studies ${ }^{(2,3)}$. However, in recent years, deep anterior lamellar keratoplasty (DALK) has been used as a safer alternative to PK. DALK consists of replacement of the anterior portion of the recipient's cornea up to the posterior limit of Descemet membrane (DM) with donor corneal tissue ${ }^{(4)}$. This procedure has been shown to reduce the long-term risk of rejection and failure of the donor graft because it avoids unnecessary replacement of the host's healthy endothelium ${ }^{(5)}$

Fewer complications arise from use of the DALK technique in comparison to traditional penetrating keratoplasty (PK), which may result in the development of anterior synechiae, secondary glaucoma, endophthalmitis, retinal detachment, and cystoid macular edema ${ }^{(6)}$.
It also offers improved ocular structural integrity against blunt trauma, since DM remains intact ${ }^{(7,8)}$. In addition, a wider selection of donor corneal tissue may be available $e^{(7,9)}$.

Use of the big-bubble technique during DALK allows deeper dissection of the anterior corneal stroma and is known to provide enhanced visual outcomes ${ }^{(0,11)}$. However, this lamellar technique involves a long learning curve, which can pose a challenge for many corneal surgeons ${ }^{(10)}$.

Several studies have shown that visual acuity (VA) in patients with keratoconus after DALK with the big-bubble technique are similar to that of those who underwent $\mathrm{PK}^{(12-18)}$, yet there is little published data with respect to preparation of the donor corneal button. Some authors have suggested that removing the endothelium of the donor corneal graft results in an improved interface ${ }^{(19-21)}$. Hallermann removed the endothelial layer and the DM of donor corneas in order to
Submitted for publication: March 8, 2016

Accepted for publication: July 23, 2016

Department of Ophthalmology and Visual Sciences, Escola Paulista de Medicina (EPM), Universidade Federal de São Paulo (UNIFESP), São Paulo, SP, Brazil.

Hospital Oftalmológico de Sorocaba, Sorocaba, SP, Brazil.
Funding: No specific financial support was available for this study.

Disclosure of potential conflicts of interest: None of the authors have any potential conflicts of interest to disclose.

Corresponding author: Tatiana Moura Bastos Prazeres. Rua Conselheiro Correia de Menezes, 266/701 - Salvador, BA - 40295-030 - Brazil - E-mail: tatianambprazeres@gmail.com

Approved by the following research ethics committee: Hospital Oftalmológico de Sorocaba (\# 1.326.225). 
avoid inflammatory reactions, as well as to reduce the possibility of interface scarring or wrinkling. Anwar suggested that by removing the endothelium and DM, a smooth surface of the posterior stroma could better be preserved ${ }^{(7)}$.

However, during the tissue preparation process, the removal of donor endothelium may cause mechanical trauma to the donor button, resulting in surface irregularities and interface scarring and, consequently, worse visual outcomes. Feizi et al. conducted a study using confocal microscopy to compare cellular changes in corneal tissue following DALK versus PK in keratoconic eyes. These authors concluded that keratocyte density was reduced following DALK and further suggested that the mechanical trauma secondary to the removal of the donor corneal endothelium may have a deleterious effect ${ }^{(18)}$. In a recent retrospective confocal study evaluating transplanted corneas with the DM left intact, the authors described keratocyte profiles and distributions in the transplanted corneas similar to those they found in normal corneas. In contrast, when the DM was removed, they reported significant changes in cellular graft profiles ${ }^{(19)}$. A further advantage of leaving the donor DM intact is that, in the event of a double anterior chamber due to a micro- or macroperforation of the recipient DM, transplantation can still be performed without compromise of the donor graft.

Comparative studies found no significant differences after DALK in VA and contrast sensibility, irrespective of whether the donor endothelium was removed or left attached ${ }^{(20-23)}$. The present study aimed to evaluate visual outcomes in patients with keratoconus undergoing DALK using full-thickness donor endothelial grafts.

\section{METHODS}

Charts from 255 consecutive patients with keratoconus undergoing DALK using the big-bubble technique from January to November 2009 at the Sorocaba Eye Hospital (Sorocaba, Brazil) were reviewed. The records of those who received a donor cornea with the DM and endothelium intact were included in the study. The patients mostly had keratoconus stage III or IV, with no history of other clinical or surgical procedure, such as contact lenses or intrastromal corneal rings. Records of patients without complete data or who had complications during the surgical procedure, such as perforation of the recipient DM, were excluded from the analysis.

All surgical procedures were performed under retrobulbar or general anesthesia using the big-bubble technique. Partial thickness trephination was performed, and a 30-gauge needle attached to an air-filled $3 \mathrm{ml}$ plastic syringe was inserted bevel-down at the peripheral trephination and advanced centripetally just above the DM. Air was injected in order to create a plane of cleavage between the DM and the posterior stroma. Paracentesis was then performed to lower intraocular pressure. A 15-degree slit knife was inserted into the large bubble, allowing air to escape and thereby collapsing the bubble. Cornea scissors were used to divide the anterior stroma into four sections by cutting each quadrant at the edge of the trephination. The stroma was removed, exposing the DM.

Donor corneas were trephined to a final size $0.25 \mathrm{~mm}$ larger than the recipient's button. In all cases, the DM and endothelium were left attached to the donor cornea. The donor button was sutured in place using 16 10-0 nylon interrupted sutures. All surgeries were performed by one of eight different surgeons, who were all second-year cornea service fellows.

Postoperative medication included moxifloxacin eye drops every $6 \mathrm{~h}$ until full corneal epithelialization, as well as $1 \%$ prednisolone eye drops every $2 \mathrm{~h}$, then tapered over subsequent weeks. All individuals were asked to return to evaluate final VA while wearing rigid gas permeable contact lenses. VA was measured using the Early Treatment Diabetic Retinopathy Study (ETDRS) chart.

Patient characteristics including age, gender, and preoperative uncorrected VA (UCVA) and spectacle-corrected VA (SCVA) were recor- ded. UCVA, endothelial cell density, and keratometry values were evaluated at 7, 30, 180 days, and 1 year postoperatively. The occurrence of graft rejection was also reported.

All individuals included in the study had been contacted by letter requesting their return at least 1 year after DALK procedure to test SCVA and VA using rigid gas-permeable contact lenses (CLVA). VA data were converted to logMAR (logarithm of the minimum angle of resolution) for statistical analysis. Pre- and postoperative VA measurements were compared using the Wilcoxon signed rank test. Analyses were performed using Stata v.11 software (College Station, Texas), and $p$ values $<0.05$ were considered statistically significant.

\section{RESULTS}

A total of 90 eyes from 90 individuals met the inclusion criteria and were included in the study. Mean ( \pm standard deviation [SD]) age was 24.6 ( \pm 9.0$)$, and $53.3 \%$ were male.

The preoperative mean ( \pm SD) UCVA was $1.88( \pm 0.52) \log M A R$ (Snellen, 20/1500) compared with post-operative UCVA at 7 days (0.91 $[ \pm 0.54], 20 / 160, p<0.001), 30$ days (0.98 [ \pm 0.61$], 20 / 190$, $p<0.001), 180$ days $(0.81[ \pm 0.63], 20 / 130, p<0.001)$, and 1 year $(0.84$ $[ \pm 0.66], 20 / 140, p<0.001)$ (Figure 1).

The preoperative SCVA of 0.57 ( \pm 0.25) LogMAR (Snellen, 20/70), improved after 1 year to 0.22 ( \pm 0.21 ) (Snellen, 20/32, $p<0.001$ ). Similarly, a significant improvement was also seen when compared to 1 year-postoperative visit CLVA (0.11 [ \pm 0.09$], 20 / 25, p<0.001)$ (Figure 2).

Pre- and postoperative average keratometry were $60.9 \pm 7.1 \mathrm{D}$ and $45.3 \pm 5.7 \mathrm{D}$, respectively $(\mathrm{p}<0.001)$. Postoperative endothelial cell density was $2550.4 \pm 436.6$ cells $/ \mathrm{cm}^{2}$.

Graft rejection was not seen after up to 48 months of follow-up in this population.

\section{DISCUSSION}

The present study evaluated VA after performing DALK surgery without removing the donor endothelium. Postoperative BCVA scores were improved over preoperative values in all patients. These visual outcomes are comparable to results obtained in other studies using the big-bubble technique but involving the removal of the donor endothelium ${ }^{(15,16,23)}$.

The incidence of graft rejection following DALK has been reported to range from $0 \%$ to $9.6 \%$ in various series ${ }^{(13,24,25)}$. This is significan-

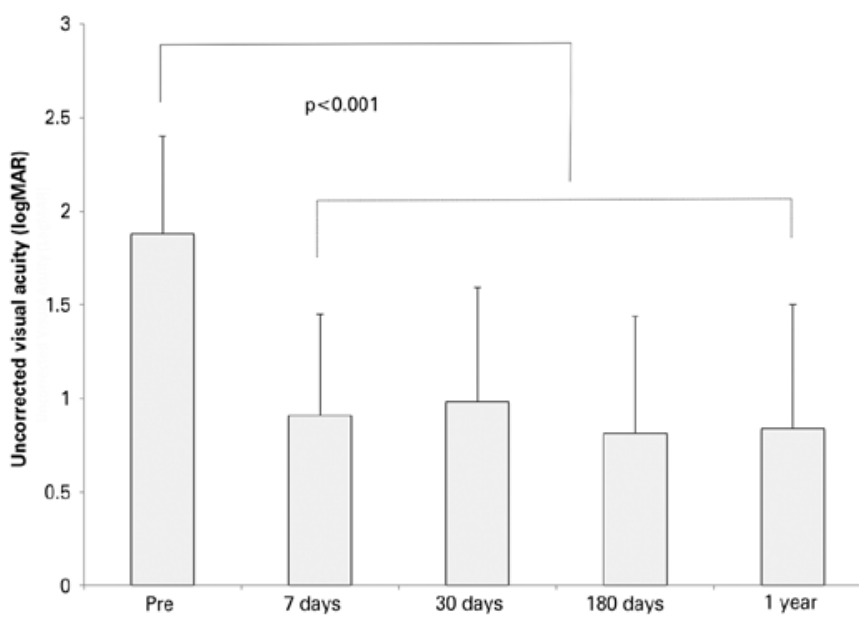

Figure 1. Mean uncorrected visual acuity before and at various times after deep anterior lamellar keratoplasty without removal of the donor Descemet membrane and endothelium. 


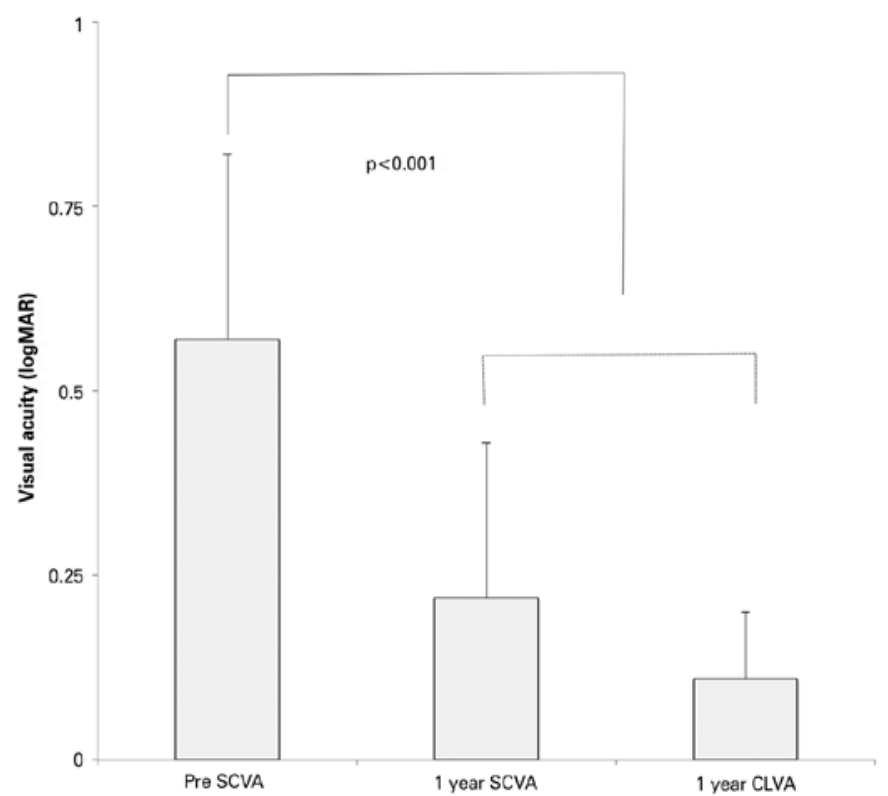

SCVA: spectacle-corrected visual acuity; CLVA: contact lens-corrected visual acuity

Figure 2. Mean preoperative spectacle-corrected visual acuity (SCVA) and SCVA and contact lens-corrected visual acuity (CLVA) 1 year after deep anterior lamellar keratoplasty without removal of the donor Descemet membrane and endothelium.

tly lower than the reported rates of 4\%-31\% following PK in patients with keratoconus ${ }^{(25,26)}$. We found no instances of graft rejection at 48 months of follow-up in our patients. It has been suggested that retaining the donor DM and endothelium might increase the antigenic load of the corneal graft ${ }^{(20)}$. Our results demonstrate that this does not appear to be a problem.

A recently conducted clinical trial comparing visual outcomes in patients undergoing DALK with and without removal of the donor DM and endothelium had results similar to ours(22).

We understand that the retrospective, non-comparative nature of this study has limitations. Nonetheless, the authors feel that it makes a contribution to current knowledge by increasing the number of keratoconic eyes evaluated with respect to BCVA after DALK using the big-bubble technique while leaving the donor DM and endothelium intact.

In conclusion, DALK utilizing donor corneas with DM and endothelium left attached is a viable alternative to endothelial removal, as patients with keratoconus obtain satisfactory VA after this procedure.

\section{REFERENCES}

1. Cosar CB, Sridhar MS, Cohen EJ, Held EL, Alvim P de T, Rapuano CJ, et al. Indications for penetrating keratoplasty and associated procedures, 1996-2000. Cornea. 2002;21(2): 148-51.
2. Javadi MA, Motlagh BF, Jafarinasab MR, Rabbanikhah Z, Anissian A, Souri H, et al. Outcomes of penetrating keratoplasty in keratoconus. Cornea. 2005;24(8):941-6.

3. The Australian Corneal graft registry. 1990 to 1992 report. Aust N Z J Ophthalmol. 1993; 21(2 Suppl):1-48.

4. Höfling AL, Nishiwaki-Dantas MC, Alves MR. Doenças externas oculares e córnea. São Paulo: Cultura Médica; 2006.

5. Fontana L, Parente G, Sincich A, Tassinari G. Influence of graft host interface on the quality of vision after deep anterior lamellar keratoplasty in patients with keratoconus. Cornea. 2011;30(5):497-502.

6. Shimazaki J. The evolution of lamellar keratoplasty. Curr Opin Ophthalmol. 2000;11(4): 217-23.

7. Anwar M, Teichmann KD. Deep Lamellar keratoplasty: surgical techniques for anterior lamellar keratoplasty with and without baring of Descemet's membrane. Cornea. 2002;21(4):374-83. Comment in: Cornea. 2007;26(1):117; author reply 117-8.

8. Lee WB, Mathys KC. Traumatic wound dehiscence after deep anterior lamellar keratoplasty. J Cataract Refract Surg. 2009:35(6):1129-31.

9. Marchini G, Mastropasqua L, Pedrotti E, Nubile M, Ciancaglini M, Sbabo A. Deep lamellar keratoplasty by intracorneal dissection-a prospective clinical and confocal microscopic study. Ophthalmology. 2006:113(8):1289-300

10. Melles GR, Lander F, Rietveld FJ, Remeijer L, Beekhuis WH, Binder PS. A new surgical technique for deep stromal anterior lamellar keratoplasty. Br J Ophthalmol. 1999;83(3): 327-33.

11. Tan DT, Mehta JS. Future directions in lamellar corneal transplantation. Cornea. 2007; 26(9 Suppl 1):S21-8.

12. Shimazaki J, Shimmura S, Ishioka M, Tsubota K. Randomized clinical trial of deep lamellar keratoplasty vs penetrating keratoplasty. Am J Ophthalmol. 2002;134(2):159-65.

13. Watson SL, Ramsay A, Dart JK, Bunce C, Craig E. Comparison of deep lamellar keratoplasty and penetrating keratoplasty for keratoconus. Ophthalmology. 2004;111(9): 1676-82.

14. Funnell CL, Ball J, Noble BA. Comparative cohort study of the outcomes of deep lamellar keratoplasty and penetrating keratoplasty for keratoconus. Eye (Lond). 2006: 20(5):527-32. Comment in: Eye (Lond). 2006;20(5):519-20.

15. Kubaloglu A, Sari ES, Unal M, Koytak A, Kurnaz E, Cinar Y, et al. Long-term results of deep anterior lamellar keratoplasty for the treatment of keratoconus. Am J Ophthalmol. 2011;151(3):760-7

16. Fontana L, Parente G, Tasinari G. Clinical outcomes after deep anterior lamellar keratoplasty using the big bubble technique in patients with keratoconus. Am J Ophthalmol. 2007; 143(1):117-24.

17. Cheng Y, Visser N, Schoutenet JS, Wijdh RJ, Pels E, van Cleynenbreugel H, et al. Endothelial cell loss and visual outcome of deep anterior lamellar keratoplasty versus penetrating keratoplasty: a randomized multicenter clinical trial. Ophthalmology. 2011; 118(2):302-9.

18. Feizi S, Javadi MA, Kanavi MR. Cellular changes of donor corneal tissue after deep anterior lamellar keratoplasty versus penetrating keratoplasty in eyes with keratoconus: a confocal study. Cornea. 2010;29(8):866-70.

19. Feizi S, Zare M, Hosseini SB, Kanavi MR, Yazdani S. Donor Descemet-off versus Descemet-on deep anterior lamellar keratoplasty: a confocal scan study. Eur J Ophthalmol. 2015:25(2):90-5.

20. Zare M, Feizi S, Hasani H, Silbert D. Comparison of descemet-on versus descemet-off deep anterior lamellar keratoplasty. Cornea. 2013;32(11):1437-40.

21. Abdelkader A, Elewah El-Sayed M, Kaufman HE. Confocal microscopy of corneal wound healing after deep lamellar keratoplasty in rabbits. Arch Ophthalmol. 2010; 128(1):75-80.

22. Prazeres TM, Muller RT, Rayes T, Hirai FE, de Sousa LB. Comparison of descemet-on versus descemet-off deep anterior lamellar keratoplasty in keratoconus patients: a randomized trial. Cornea. 2015;34(7):797-801. Comment in: Cornea. 2016;35(1):e1.

23. Feizi S, Javadi M, Jamali H, Mirbabaee F. Deep anterior lamellar keratoplasty in patients with keratoconus: big-bubble technique. Cornea. 2010;29(2):177-82

24. Coombes AG, Kinwan JF, Rostron CK. Deep lamellar keratoplasty using lyophilized tissue in the management of keratoconus. Br J Ophthalmol. 2001;85(7):788-91.

25. Olson RJ, Pingreen M, Ridges R, Lundergan ML, Alldredge C Jr, Clinch TE. Penetrating keratoplasty for keratoconus-a long term review of results and complications. J Cataract Refract Surg. 2000;26(7):987-91.

26. Lim L, Pseudovs K, Coster DJ. Penetrating keratoplasty for keratoconus: visual outcomes and success. Ophthalmology. 2000;107(6):1125-31. 